\title{
Building Hybrid Energy System, PV/Wind Turbine Using Local Material
}

\author{
Layth Abed Hasnawi Al-Rubaye, Itimad D.J. Azzawi and Saadoon Abdul Hafedhb \\ Department of Mechanical Engineering, College of Engineering, University of Diyala, \\ Baquba, Diyala Province, Iraq
}

\begin{abstract}
Many used materials are available around us which can be produced useful devices, especially in the field of electricity generation. Hybrid devices are one of these machines. Especially, that operate on renewable energy such as (solar, wind, water, etc.). Recently, there has been a lot of research that is particularly combining wind and solar energy as complementary to each other. Iraq has enough of this combined energy with natural potential of the astronomical location between the land and water and the climate factor which made it a region of the passage of wind through the year when the wind speed reached more than $5 \mathrm{~m} / \mathrm{sec}$ in addition to solar energy. In is the study, it was built and developed Hybrid of Solar-Wind Turbine system (HSWT) with relying on simple and low-cost component.
\end{abstract}

Key words: Solar energy, wind energy, hybrid power system, wind turbine, useful devices, water

\section{INTRODUCTION}

The renewable energy sources are great importance for cleanness and low environmental impact. Increase demand for fossil fuels (coal, oil, natural gas and uranium) worldwide has exacerbated the problem of global warming and climate change. This was an important factor for investing renewable energy sources in power generation. Iraq is an appropriate area to invest this energy in terms of location and climate. The world already is responding to these imperatives. In 2002 the world's total investments in renewable energy sector was $\$ 17$ billion with constant increase to the present (Deepchand, 2005; Lund and Mathiesen, 2009). One of the most important elements of investment success is reducing the cost of manufacturing.
While in Iraq, the share of renewable resources accounts almost to be non-existent as compared to other fossil fuels type. Figure 1 explain the story of renewable energy growth (Bhattacharya et al., 2016; McCrone et al., 2012). The Iraqi government should accelerate the development of this sector and benefit from the abundance of renewable sources of available energy, especially, the sun and wind.

There are many problems by conventional energy such as oil supply insecurity, extreme pollution and climate change risks due to fossil fuel burning. Therefore, looking for alternative non-conventional energy resources has become an urgent matter. One of the most popular non-conventional power resources are solar energy power plants which convert the solar energy or solar heat

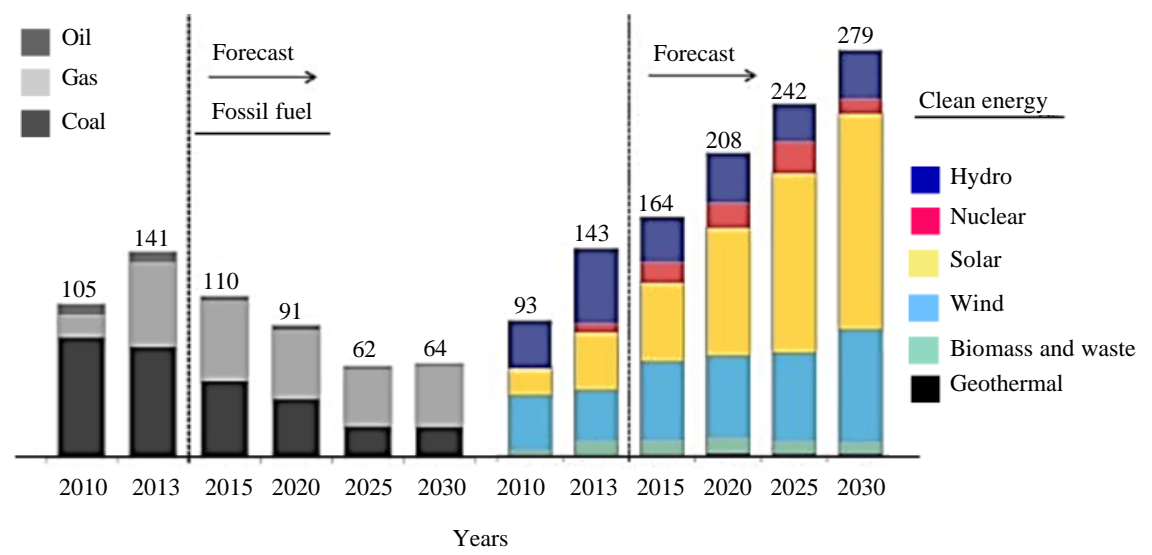

Fig. 1: Comparison of the quantities of energy sources within 30 years (McCrone et al., 2012)

Corresponding Author: Layth Abed Hasnawi Al-Rubaye, Department of Mechanical Engineering, College of Engineering, University of Diyala, Baquba, Diyala Province, Iraq 
to electricity. Yet, the disadvantage is that it does not work when there is cloudy or rainy weather. This has created the need to combine solar energy with wind energy to obtain a solid power source known as a hybrid solar wind power generation system. This study looking for building hybrid system using very low-cost material to generate electricity.

Site selected information: Figure 2 shown the location area of the Aerodynamics Laboratory at Mechanical Engineering Department, Engineering College, Diyala University to power supply residential household located.

Experimental work: The model and dimensions for the wind turbine was modulated to agree the concept to evaluate the reliability of hybrid systems. This can be seen in Fig. 3 and 4.
The project is designed in two steps, the first step is to design and manufacture while the second step is to connect the solar cell with the wind turbine and the production and storage to generate electric power. In general, the sectional shape of the Horizontal-Axis Wind Turbine (HAWT) blade consists of the airfoil which result the lift and drag forces by virtue of pressure differences across theblade surface. Because of this, the Blade Element Momentum (BEM) theory is widely used to outline the procedure for the aerodynamic design of a (HAWT) blade. The optimum distributions of the chord length and the pitch angle in each study can be acquired according to the design parameters which include the rated wind speed, number of blades, design tip speed ratio and design angle of attack (Diaf et al., 2007). The specification of photovoltaic, HAWT and battery parameter are clearly shown in Table 1-3.

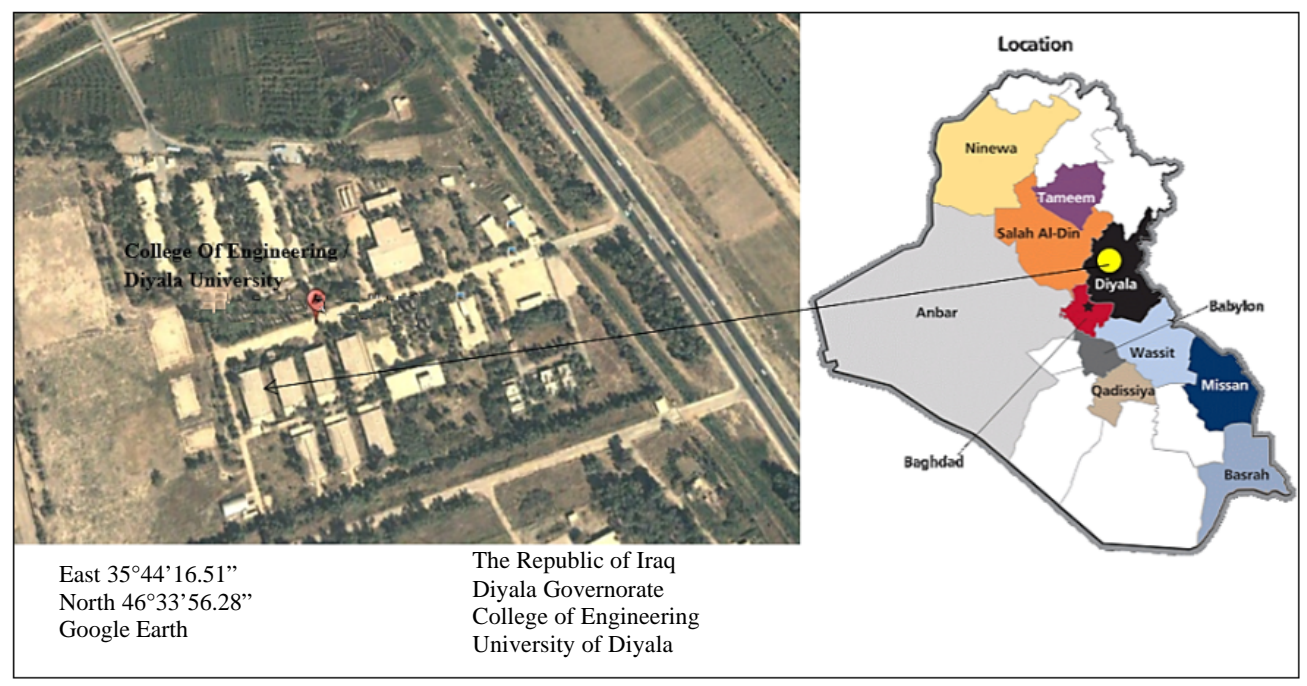

Fig. 2: Geographical location to conduct the experiment

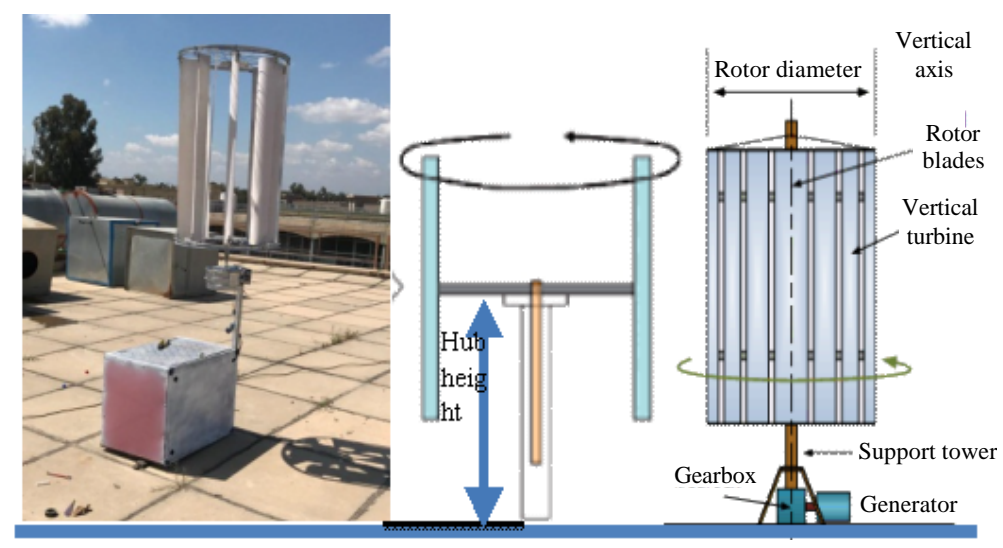

Fig. 3: Horizontal-Axis Wind Turbine (HAWT) blade section 


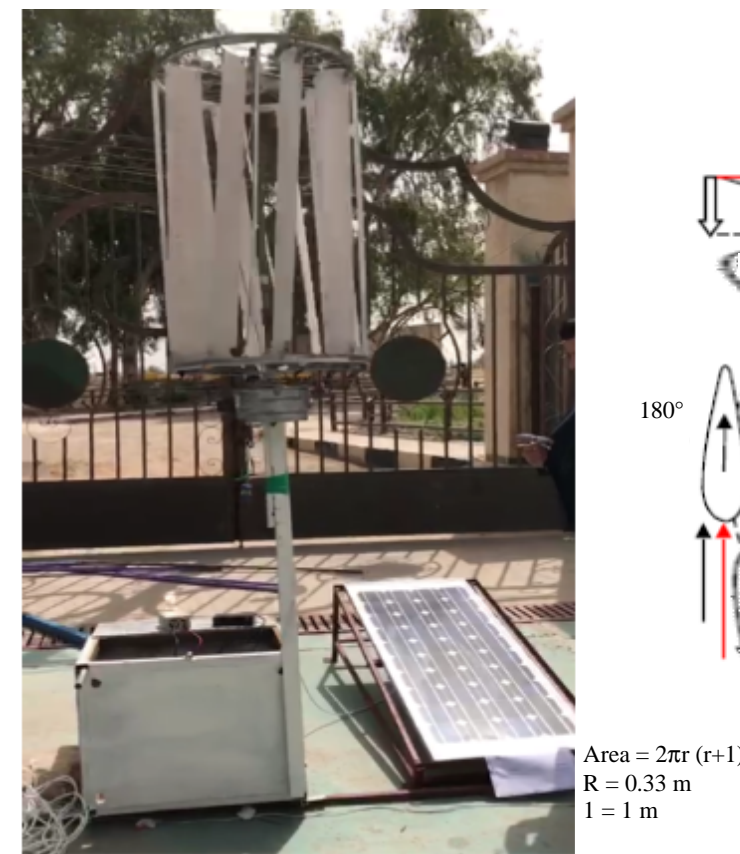

Fig. 4: The Blade Element Momentum (BEM) design of a (HAWT)

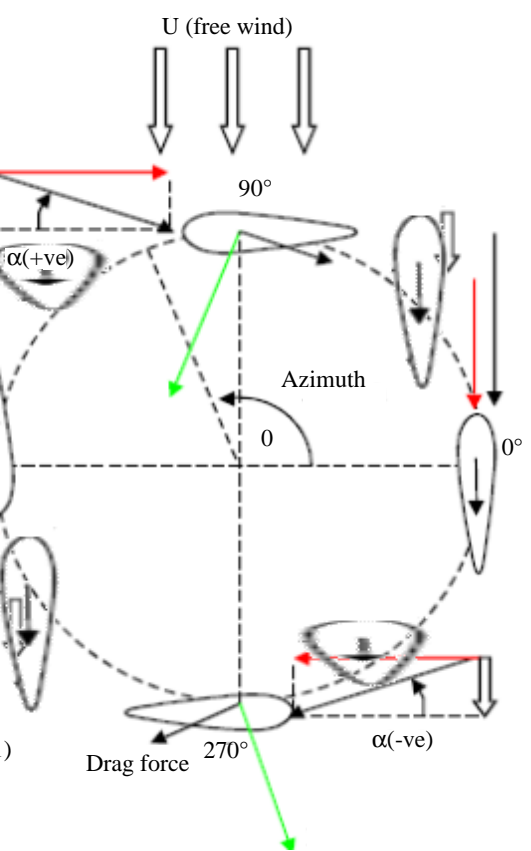

Life force
Table 1: Wind Turbine (HAWT) modules parameters

\begin{tabular}{|c|c|c|c|}
\hline \multicolumn{2}{|c|}{ Wind turbine (HAWT) } & \multicolumn{2}{|l|}{ Blade } \\
\hline Diameter & $40 \mathrm{~cm}$ & Diameter & $10 \mathrm{~cm}$ \\
\hline Length & $1.7 \mathrm{~m}$ & Number of wheels & $\begin{array}{l}2 \text { bicycle wheelsused } \\
\text { to fix the blade in } \\
\text { booth side with } \\
\text { diameter }(0.66 \mathrm{~m})\end{array}$ \\
\hline Cost of Pipe & $8 \$$ & & $\begin{array}{l}\text { The end of the blade is } \\
\text { converted to by fit to } \\
\text { the required design }\end{array}$ \\
\hline
\end{tabular}

Number of sections 4

Table 2: Photovoltaic and wind turbine modules parameters

\begin{tabular}{|c|c|c|c|c|}
\hline Variables & Values & Variables & \multicolumn{2}{|l|}{ Values } \\
\hline PV & & Wind turbine & \multirow{2}{*}{\multicolumn{2}{|c|}{$0.75 \mathrm{~m} / \mathrm{sec}$}} \\
\hline Rated maximum & $90 \mathrm{~W}$ & Start wind speed & & \\
\hline Operating voltage & $12 \mathrm{~V}$ & Rated voltage & \multicolumn{2}{|c|}{$12 \mathrm{~V}$} \\
\hline Current at pmax & $5.17 \mathrm{~A}$ & Rated power & \multicolumn{2}{|l|}{$10-120 \mathrm{~W}$} \\
\hline Voltage at pmax & $17.4 \mathrm{~V}$ & $\begin{array}{l}\text { Wind turbine } \\
\text { material }\end{array}$ & \multicolumn{2}{|c|}{ Plastic+Aluminum } \\
\hline Short circuit voltage & $5.9 \mathrm{~A}$ & No. of wings & \multicolumn{2}{|l|}{8} \\
\hline Open circuit voltage & $12.4 \mathrm{~V}$ & Fan diameter & \multicolumn{2}{|l|}{$0.66 \mathrm{~m}$} \\
\hline $\begin{array}{l}\text { Nominal operation } \\
\text { cell temp }\end{array}$ & $50^{\circ} \mathrm{C}$ & Total weight & \multicolumn{2}{|l|}{$8 \mathrm{~kg}$} \\
\hline Angle of inclination & \multicolumn{4}{|l|}{$45^{\circ}$} \\
\hline \multicolumn{5}{|c|}{$\begin{array}{l}\text { As for the solar cell, it is used at a price of } 110 \$ \text { with accessories at a total } \\
\text { price }(165 \$)\end{array}$} \\
\hline \multicolumn{5}{|c|}{ Table 3: Battery parameters } \\
\hline Type & $\begin{array}{l}\text { Nominal } \\
\text { capacity (Ah) }\end{array}$ & Voltage (V) & $\begin{array}{l}\text { Minimum } \\
\text { charge }\end{array}$ & Cost (\$) \\
\hline $\begin{array}{l}\text { ATRX-80d } 261 \\
70 \mathrm{Ah} 256 * 175 * 200 \\
222 \mathrm{~mm}\end{array}$ & 80 & 12 & $18 \%$ & $45 \$$ \\
\hline
\end{tabular}

The design stages of wind turbine including the battery, controller and inverter are shown in Fig. 5.
Figure 4 clearly showed how the parts were connected to each other with the power storage.

Theoretical methods: In this study, the power law is applied for the vertical wind speed profile applicable to turbine type Horizontal-Axisto find the velocity of wind turbine (Diaf et al., 2007):

$$
\mathrm{V}=\mathrm{V}_{0}\left[\frac{\mathrm{H}}{\mathrm{H}_{0}}\right]^{\alpha .1}
$$

Where:

$\mathrm{V}=$ The wind speed at hub Height $(\mathrm{H})$

$\alpha_{1}=$ The power law exponent which varies with elevation

$\mathrm{V}_{0}=$ The wind speed measured at the reference height $\mathrm{H}_{0}$

To calculate the amount of electrical energy generated by the system, possible follow these steps. Total power generated an hour ( $t$ ) is calculated by combine between the wind turbine and PV generator power as follows (Diaf et al., 2008):

$$
P_{\text {tot }}(t)=P_{P V}(t)+P_{W G}(t)
$$

$\mathrm{P}_{\mathrm{PV}}(\mathrm{t})=90 \mathrm{w}$ form specifications of PV that using in the model. The power generator of wind turbine can be defined as: 
(a)

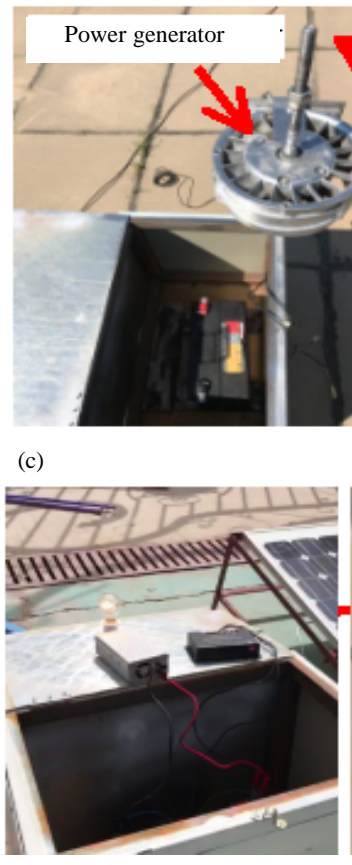

(b)

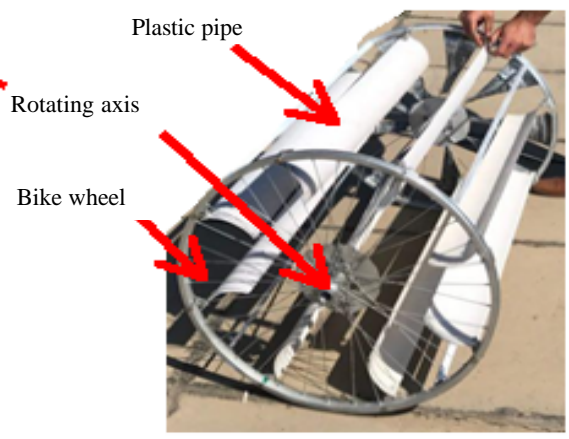

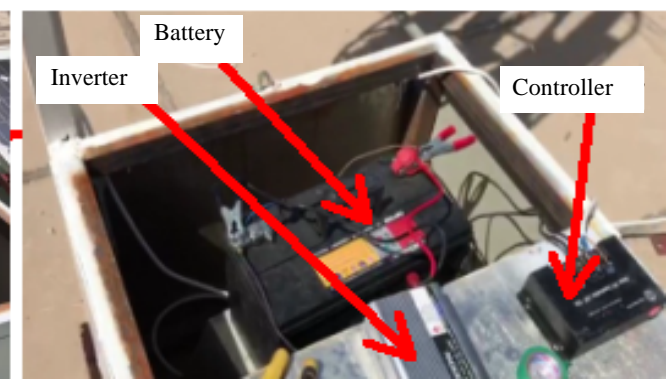

Fig. 5: Design stage of (HAWT) used in the experiment: a) Power generator; b) Wend turbine design and c) Solar controller $24 \mathrm{~V}$ LSA and storage battery

$$
P_{\mathrm{WG}}(\mathrm{t})=\frac{1}{2} \times \rho \times \mathrm{A} \times \mathrm{V}_{0}^{3}
$$

Also, to calculate the inverter input power by using Eq. 4 :

$$
P_{\text {inv }}(t)=\frac{P_{\text {load }}(t)}{\eta_{\text {inv }}}
$$

Where:

$\mathrm{P}_{\text {inv }}=$ The Power consumed by the load at hour $\mathrm{t}$

$\eta_{\text {inv }}=$ The inverter efficiency will be fixed at $85 \%$

There is relationship between turbine type, wind speed with engineering requirements of a wind turbine that named of power Coefficient $\left(\mathrm{C}_{\mathrm{p}}\right)$. The theoretical $\mathrm{C}_{\mathrm{pmax}}$ of any design equal 59\% (Manyonge et al., 2012) of the turbine includes gearbox, bearings and generator that effects on thepower of the wind, so, $\mathrm{C}_{\mathrm{p}}$ is very important. Accordingly, $\mathrm{C}_{\mathrm{p}}$ needs to extractable power from the wind through Eq. 3:

$$
\mathrm{P}_{\mathrm{aral}}=\frac{1}{2} \rho \mathrm{Av}^{3} \mathrm{C}_{\mathrm{p}}
$$

The process of transfer power output from PV and wind generators to the battery can be described by state-of-charge process, consumption situation of the system during the time from (t-1-t) during the charging process:

$$
\begin{aligned}
& C_{\text {bat }}(t)=C_{\text {bat }}(t-1) \cdot(1-\sigma)+ \\
& \left(E_{P V}(t)+E_{W G}(t)-\frac{E_{L}(t)}{\eta_{\text {inv }}}\right) \eta_{\text {bat }}
\end{aligned}
$$

Where:

$\mathrm{C}_{\mathrm{bat}}(\mathrm{t})=$ Capacity of battery available

$\mathrm{C}_{\mathrm{bat}}(\mathrm{t}-1)=$ Bank Capacity $(\mathrm{Wh})$

$\mathrm{E}_{\mathrm{PV}}(\mathrm{t}) \quad=$ Energy generated by $\mathrm{PV}=90(\mathrm{~W}) \mathrm{t}$

$E_{W G}(t)=P_{W G}=$ Power fromwind generators can be

(W)t taken from Table 3

$\mathrm{E}_{\mathrm{L}}(\mathrm{t}) \quad=$ The load demand at hour $\mathrm{t}$

$\eta_{\text {bat }}=$ The battery efficiency $=0.65-0.85$ take $77.3 \%$ in this type (Li et al., 2012)

$\eta_{\text {inv }} \quad=$ The inverter efficiency $=85 \%$

$\sigma \quad=$ Self-discharge rate of the battery bank $=$ $20 \%$ per month (McEvoy et al., 2003)

Table 4 and 5 contains the details of the storage capacity of the battery. To calculate the time required to store the battery, the following equation can be used (Ai et al., 2003; Guo and Sharma, 2016; Li et al., 2012):

$$
\mathrm{C}_{\mathrm{T}}=\mathrm{C}_{\mathrm{battery}}(\mathrm{t}) / \mathrm{P}_{\text {tot }}(\mathrm{t})
$$

Where:

$\mathrm{C}_{\mathrm{T}} \quad=$ Equal Charging time $(\mathrm{h})$

$\mathrm{C}_{\text {battery }}=$ Battery capacity (Ah)

$\mathrm{P}_{\text {tot }} \quad=$ The amount of power fitted to the battery measured (A) 
Table 4: Values obtained from the experiment work for HPWS at level $(7.5 \mathrm{~m})$ Test information (time)

\begin{tabular}{|c|c|c|c|c|c|c|}
\hline No. of test & Start & End & Data & Wind observation $\left(\mathrm{V}_{0}\right)(\mathrm{m} / \mathrm{sec})$ & Voltage (V) & $\mathrm{PPV}(\mathrm{V})$ \\
\hline \multirow[t]{4}{*}{1} & $10: 00 \mathrm{am}$ & $10: 15 \mathrm{am}$ & $14 / 2 / 2017$ & 3.1 & 18 & 12 \\
\hline & $10: 15 \mathrm{am}$ & $10: 30 \mathrm{am}$ & & 3.6 & 20 & 12 \\
\hline & $10: 30 \mathrm{am}$ & $10: 45 \mathrm{am}$ & & 2.6 & 15 & 12 \\
\hline & $10: 45 \mathrm{am}$ & $11: 00 \mathrm{am}$ & & 4.2 & 23 & 12 \\
\hline \multirow[t]{5}{*}{2} & $8: 00 \mathrm{am}$ & $8: 10 \mathrm{am}$ & $20 / 3 / 2017$ & 2.2 & 11 & 12 \\
\hline & $8: 10 \mathrm{am}$ & $8: 20 \mathrm{am}$ & & 3.0 & 18 & 12 \\
\hline & $8: 20 \mathrm{am}$ & $8: 30 \mathrm{am}$ & & 3.5 & 19 & 12 \\
\hline & $8: 30 \mathrm{am}$ & $8: 40 \mathrm{am}$ & & 2.0 & 10 & 12 \\
\hline & $8: 40 \mathrm{am}$ & $9: 00 \mathrm{am}$ & & 3.0 & 18 & 12 \\
\hline \multirow[t]{2}{*}{3} & $12: 00 \mathrm{pm}$ & $12: 15 \mathrm{pm}$ & $6 / 4 / 2017$ & 4.0 & 21 & 12 \\
\hline & $12: 15 \mathrm{pm}$ & $12: 30 \mathrm{pm}$ & & 2.6 & 15 & 12 \\
\hline \multirow[t]{2}{*}{4} & $2: 00 \mathrm{pm}$ & $2: 15 \mathrm{pm}$ & $20 / 5 / 2017$ & 2.8 & 16 & 12 \\
\hline & $2: 15 \mathrm{pm}$ & $2: 30 \mathrm{pm}$ & & 3.4 & 19 & 12 \\
\hline
\end{tabular}

Table 5: Calculate the wind speed V $(\mathrm{m} / \mathrm{sec})$ at hub $(1 \mathrm{~m})$

\begin{tabular}{lllllc} 
Speed & $\mathrm{V}_{0}(\mathrm{~m} / \mathrm{sec})$ & $\mathrm{H}(\mathrm{m})$ & $\mathrm{H}_{0}(\mathrm{~m})$ & $\alpha_{1}$ & $\mathrm{~V}(\mathrm{~m} / \mathrm{sec})$ \\
Low & 2 & 1 & 1.5 & 0.5 & 1.633 \\
Medium & 3.6 & 1 & 1.5 & 0.5 & 2.939 \\
High & 4.2 & 1 & 1.5 & 0.5 & 3.429 \\
Low & 2 & 1 & 1.5 & 0.4 & 1.701 \\
Medium & 3.6 & 1 & 1.5 & 0.4 & 3.061 \\
High & 4.2 & 1 & 1.5 & 0.4 & 3.571 \\
Low & 2 & 1 & 1.5 & 0.3 & 1.771 \\
Medium & 3.6 & 1 & 1.5 & 0.3 & 3.188 \\
High & 4.2 & 1 & 1.5 & 0.3 & 3.719 \\
Low & 2 & 1 & 1.5 & 0.27 & 1.793 \\
Medium & 3.6 & 1 & 1.5 & 0.27 & 3.227 \\
High & 4.2 & 1 & 1.5 & 0.27 & 3.764 \\
\hline
\end{tabular}

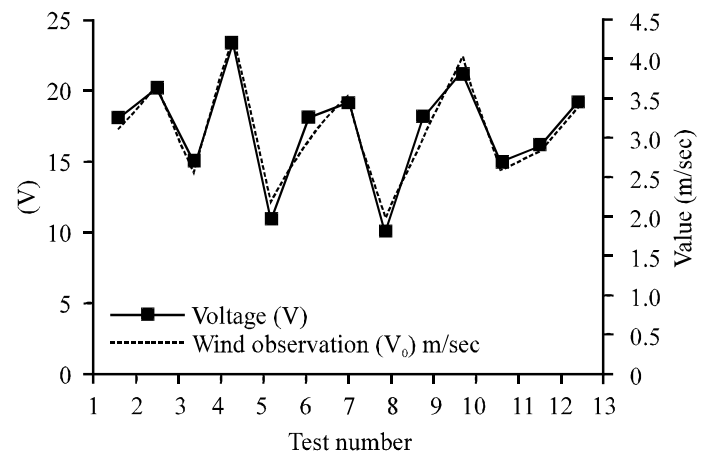

Fig. 6: Relation ship between wind speed and voltage of (HAWT)

\section{RESULTS AND DISCUSSION}

From Table 4, the Hybrid PV/Wind System (HPWS) result was collected experimentally using digital manometer (AR836) which has accuracy of $\pm 3 \% \pm 0.1 \mathrm{dgt}$ (Table 4).

Figure 6 explains the wind power, it was taken from (McEvoy et al., 2003) readings at period between 02/14/2017-05/20/2017 about four months. Measurements were made at a specified height (7.5) $\mathrm{m}$ including $(6 \mathrm{~m}$ height of the building $+1.5 \mathrm{~m}$ hub high). The air speed was changed depending on the surrounding weather conditions resulting in different voltages increasing with increasing air velocity and vice versa.
Table 6: Calculate the total power generated an hour (t) with power consumed by the load at hour $\mathrm{t}$

\begin{tabular}{lccccc}
\hline $\mathrm{V}_{0}(\mathrm{~m} / \mathrm{sec})$ & Inv $100 \%$ & $(\mathrm{~W}) \mathrm{t}$ & $(\mathrm{W}) \mathrm{t}$ rated power & $(\mathrm{W}) \mathrm{t}$ & Pinv $(\mathrm{W}) \mathrm{t}$ \\
\hline 3.1 & 0.85 & 90 & 47.0850 & 137.085 & 161.276 \\
3.6 & 0.85 & 90 & 73.7400 & 163.740 & 192.635 \\
2.6 & 0.85 & 90 & 27.7790 & 117.779 & 138.563 \\
4.2 & 0.85 & 90 & 117.097 & 207.097 & 243.643 \\
2.2 & 0.85 & 90 & 16.8290 & 106.829 & 125.681 \\
3 & 0.85 & 90 & 42.6740 & 132.674 & 156.087 \\
3.5 & 0.85 & 90 & 67.7640 & 157.764 & 185.605 \\
2 & 0.85 & 90 & 12.6440 & 102.644 & 120.758 \\
3 & 0.85 & 90 & 42.6740 & 132.674 & 156.087 \\
4 & 0.85 & 90 & 101.152 & 191.152 & 224.885 \\
2.6 & 0.85 & 90 & 27.7790 & 117.779 & 138.563 \\
2.8 & 0.85 & 90 & 34.6950 & 124.695 & 146.700 \\
\hline
\end{tabular}

According to the measured wind velocity, the result were divided into three sections (low, medium and high) depending the mathematical statistics work between $(2,3.6$ and 4.2$) \mathrm{m} / \mathrm{sec}$. According to Eq. 1, the velocity of wind turbine was calculated and clearly showed in Table 5 .

Power law exponent $\left(\alpha_{1}\right)$, arias between $(0.6)$ for stable air and (0.27) for unstable air above human inhabited areas, however, in case neutral air above human inhabited areas take (0.34) (Kaltschmitt et al., 2006). Figure 7 explain how the wind speed increase when the power law exponent $\left(\alpha_{1}\right)$ reduced. To calculate the power consumed by the load at hour, Eq. 2-4 were used and Table 6 also shown that.

Figure 8 indicates the relationship between wind turbine andpower generator with higher wind speed a maxing power generating can be reduced. Such that higher the wind speed increases the power generation.

Thus, increasing total energy and thus, increasing the storage capacity added to the energy generated by the solar cells. This is confirmed by theoretical and practical calculations. From Eq. 5 by taken:

- $\quad{ }^{*} \rho$ equal 1.146 kg/m $\mathrm{m}^{3} @$ temperature $35^{\circ} \mathrm{C}$ (Cengel and Boles, 2002)

- $\quad{ }^{* *} \mathrm{C}_{\mathrm{p}}$ values limited between $(0.35-0.45)$ represent the best engineering design of wind turbines, it a variable with the tip speed ratio of the turbine (Manyonge et al., 2012) 


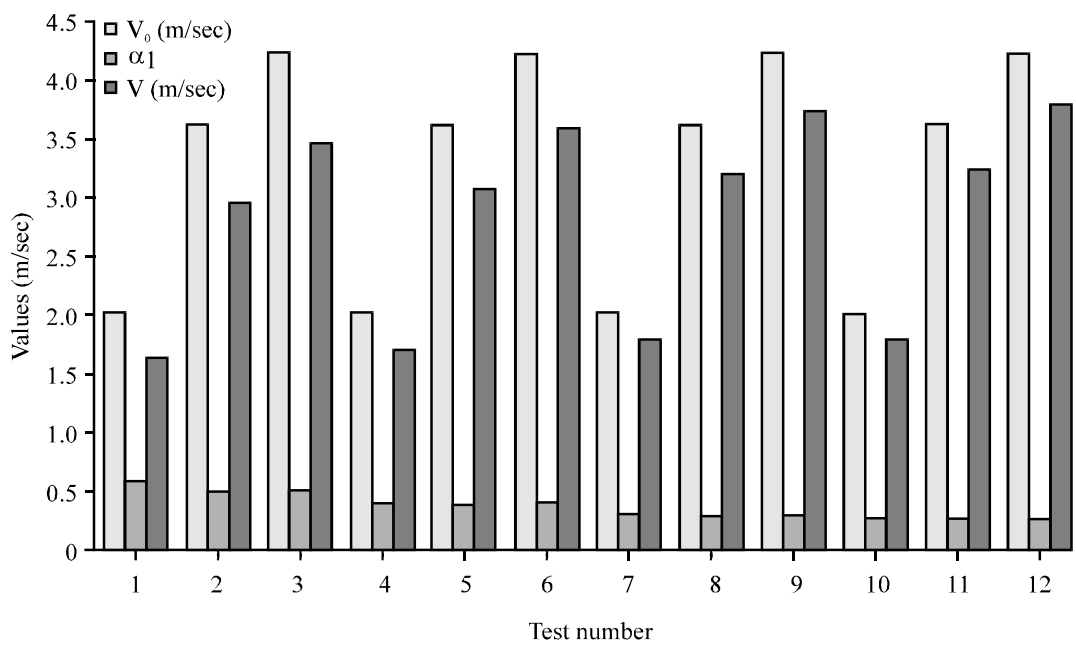

Fig. 7: Relationship between wind speed and wind turbine of HAWT

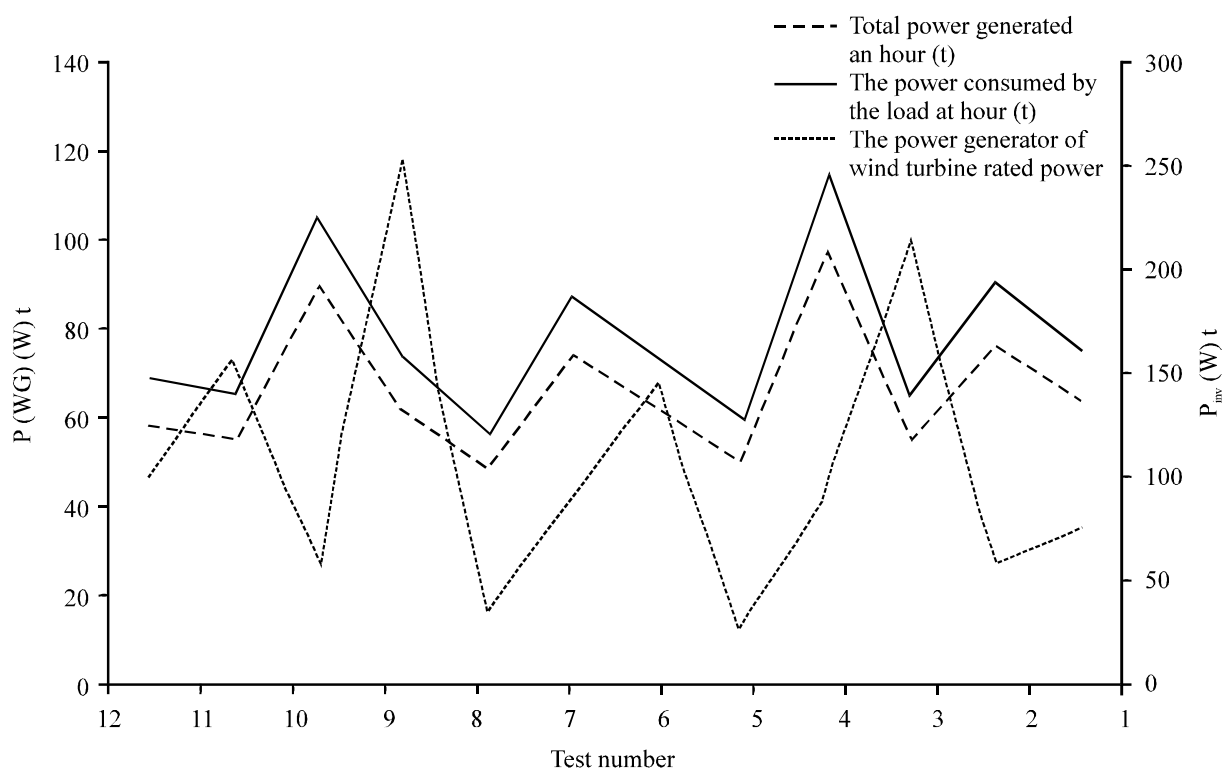

Fig. 8: Power generator of wind turbine with the power consumed for the samewind observation

Table 7: Calculate the avail power from wind generator depend on power coefficient

\begin{tabular}{llccccc}
\hline No. of test & Speed & $\mathrm{V}(\mathrm{m} / \mathrm{sec})$ & $\rho^{*}\left(\mathrm{~kg} / \mathrm{m}^{3}\right)$ & $\mathrm{A}\left(\mathrm{m}^{2}\right)$ & $\mathrm{C}_{\mathrm{p}}$ & $\mathrm{P}_{\text {avail }}(\mathrm{W})$ \\
\hline 1 & Low & 1.633 & 1.146 & 2.758 & 0.300 & 2.0650 \\
& Medium & 2.939 & 1.146 & 2.758 & 0.300 & 12.036 \\
& High & 3.429 & 1.146 & 2.758 & 0.300 & 19.115 \\
& Low & 1.701 & 1.146 & 2.758 & 0.350 & 2.7220 \\
& Medium & 3.061 & 1.146 & 2.758 & 0.350 & 15.864 \\
& High & 3.571 & 1.146 & 2.758 & 0.350 & 25.188 \\
& Low & 1.771 & 1.146 & 2.758 & 0.400 & 3.5110 \\
& Medium & 3.188 & 1.146 & 2.758 & 0.400 & 20.482 \\
& High & 3.719 & 1.146 & 2.758 & 0.400 & 32.515 \\
& Low & 1.793 & 1.146 & 2.758 & 0.450 & 4.0990 \\
& Medium & 3.227 & 1.146 & 2.758 & 0.450 & 23.898 \\
& High & 3.764 & 1.146 & 2.758 & 0.450 & 37.924 \\
\hline
\end{tabular}

Figure 9 explain how much the deference between the effect of $C_{p}$ with wind speed generator to produce power coefficient that collected in Table 7 .

The life span of this hybrid system can be considered 10 years according to the manufacturer of the solar cells. The storage battery needs to be changed several times during this period. Table 8-11 and Fig. 10 and 11 explain the capacity of battery with deferent time of charge.

From Table 4 and 7 when the capacity ofbattery generated by the PV and wind generators is negative that is mean the power needed by the load more than storage 


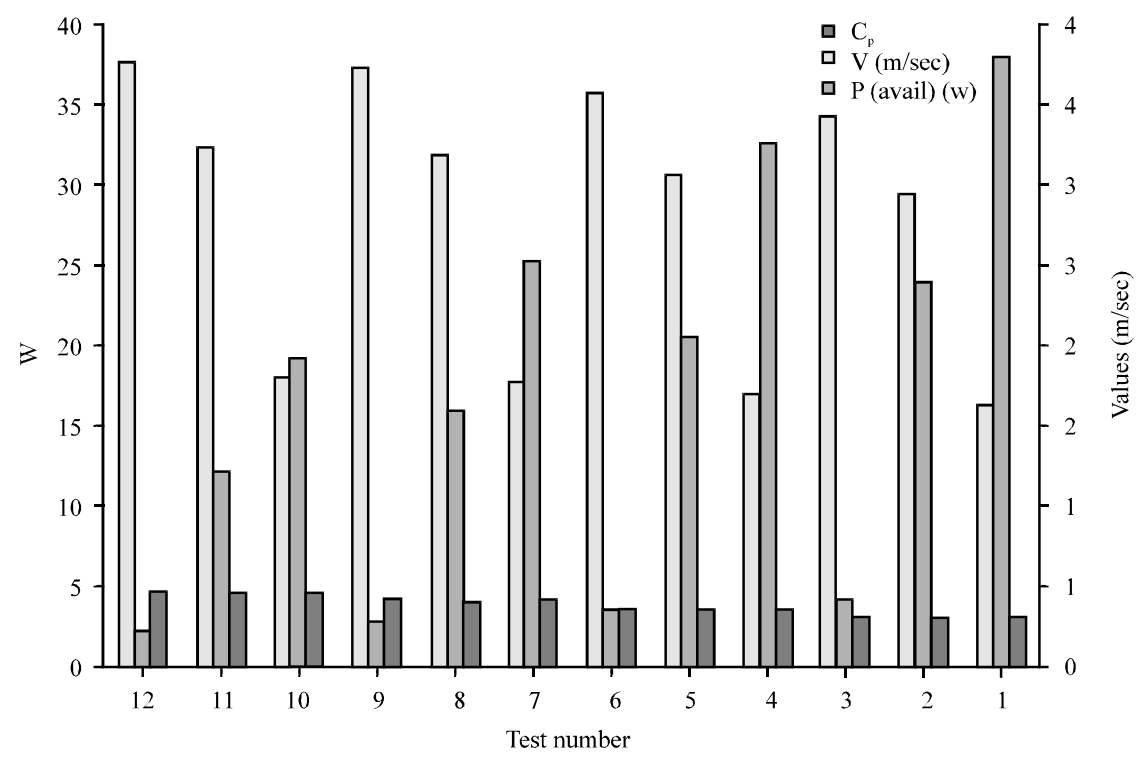

Fig. 9: Deference in avail 1 power from wind generator depend on power coefficient and $C_{p}$

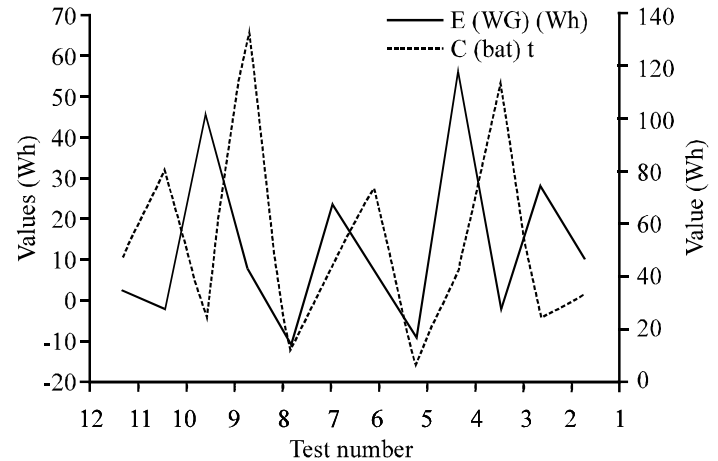

Fig. 10: The deferent in time required to charge the battery

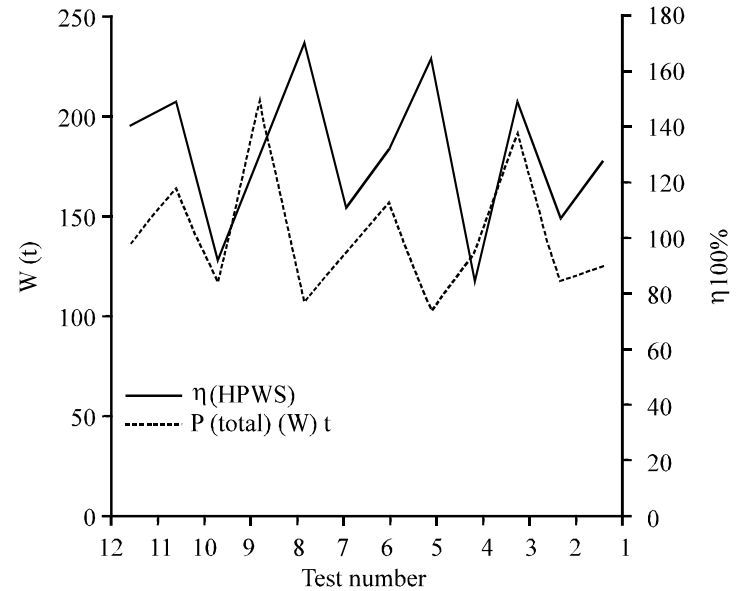

Fig. 11: HPWS efficiency

\begin{tabular}{|c|c|c|c|c|c|c|c|}
\hline $\begin{array}{l}\mathrm{C}_{\mathrm{ab}} * \\
(\mathrm{t}-1) \\
\end{array}$ & $\sigma(\%)$ & $\begin{array}{l}\mathrm{E}_{\mathrm{PV}} \\
(\mathrm{Wh})\end{array}$ & $\begin{array}{l}E_{W G} \\
(W h)^{* * *}\end{array}$ & $\begin{array}{l}\mathrm{E}_{\mathrm{L}} \\
\text { (Wh) }\end{array}$ & $\zeta_{\text {inv }}$ & $\zeta_{\text {hat }}$ & $\begin{array}{l}\mathrm{C}_{\text {bat }}(\mathrm{t}) \\
(\mathrm{Wh})\end{array}$ \\
\hline 80 & 0.2 & 90 & 47.085 & 175 & 0.85 & 0.773 & 10.820 \\
\hline 80 & 0.2 & 90 & 73.740 & 175 & 0.85 & 0.773 & 31.424 \\
\hline 80 & 0.2 & 90 & 27.779 & 175 & 0.85 & 0.773 & -4.1040 \\
\hline 80 & 0.2 & 90 & 117.097 & 175 & 0.85 & 0.773 & 64.939 \\
\hline 80 & 0.2 & 90 & 16.829 & 175 & 0.85 & 0.773 & -12.568 \\
\hline 80 & 0.2 & 90 & 42.674 & 175 & 0.85 & 0.773 & 7.4100 \\
\hline 80 & 0.2 & 90 & 67.764 & 175 & 0.85 & 0.773 & 26.805 \\
\hline 80 & 0.2 & 90 & 12.644 & 175 & 0.85 & 0.773 & -15.803 \\
\hline 80 & 0.2 & 90 & 42.674 & 175 & 0.85 & 0.773 & 7.4100 \\
\hline 80 & 0.2 & 90 & 101.152 & 175 & 0.85 & 0.773 & 52.613 \\
\hline 80 & 0.2 & 90 & 27.779 & 175 & 0.85 & 0.773 & -4.1040 \\
\hline 80 & 0.2 & 90 & 34.695 & 175 & 0.85 & 0.773 & 1.24200 \\
\hline
\end{tabular}
using ceiling fan andenergy saving lighting with 1 piece each

Table 9: The amount of time allocated to charge the battery by the hybrid system

\begin{tabular}{lll}
\hline \multicolumn{1}{c}{ system } & $\mathrm{P}_{\text {tat }}(\mathrm{A})$ & $\mathrm{C}_{\mathrm{T}}(\mathrm{h})$ \\
\hline 80 & 10.116 & 7.908 \\
80 & 11.187 & 7.151 \\
80 & 9.3520 & 8.554 \\
80 & 12.591 & 6.354 \\
80 & 9.0300 & 8.859 \\
80 & 9.8710 & 8.105 \\
80 & 11.067 & 7.229 \\
80 & 8.7640 & 9.128 \\
80 & 9.8710 & 8.105 \\
80 & 12.317 & 6.495 \\
80 & 9.3520 & 8.554 \\
80 & 9.6680 & 8.274 \\
\hline
\end{tabular}

capacity. But in the positive state, the desired load is less than the amount of stored energy and this is required to provide excess storage energy.

In order to ensure the validity and integrity of the hybrid system. Be sure to check it out or check the amount of error that accompanies the research. For this reason, we can follow the number of Eq. 8 and 9: 
Table 10: Find out how error in the HPWS Hybrid system

\begin{tabular}{llll} 
Practical & & Theoretical & \\
Voltage & $23 \mathrm{~V}$ for wind & Voltage & $12 \mathrm{~V}$ for wind \\
\hline $\mathrm{I}$ & $\mathrm{R}=2.2 \mathrm{R}, \mathrm{I}=\mathrm{V} / \mathrm{RI}$ & $\mathrm{I}$ & $5 \mathrm{~A}$ \\
\multirow{2}{*}{ Power } & $\begin{array}{l}\mathrm{N}=23 / 220=0.105 \mathrm{~A} \\
\mathrm{P}=\mathrm{V}^{*} \mathrm{I}=23^{*}\end{array}$ & Power (total) & $\begin{array}{l}\mathrm{P}=\mathrm{V} * \mathrm{I}= \\
12^{*} 5=60 \mathrm{~W}\end{array}$ \\
\hline
\end{tabular}

Error $=2.405 / 60=0.04=4 \%$

Table 11: The efficient in the HPWS

\begin{tabular}{lrr}
\hline Pload W(h) & $\mathrm{P}_{\text {total }}(\mathrm{W}) \mathrm{t}$ & $\zeta \mathrm{HPWS}$ \\
\hline 175 & 137.085 & 127.658 \\
175 & 163.740 & 106.877 \\
175 & 117.779 & 148.583 \\
175 & 207.097 & 84.5010 \\
175 & 106.829 & 163.813 \\
175 & 132.674 & 131.902 \\
175 & 157.764 & 110.925 \\
175 & 102.644 & 170.492 \\
175 & 132.674 & 131.902 \\
175 & 191.152 & 91.5500 \\
175 & 117.779 & 148.583 \\
175 & 124.695 & 140.342 \\
\hline
\end{tabular}

$$
\begin{gathered}
\text { Error }=\text { Practical } / \text { Theoretical } \\
\zeta_{\text {HPWS }}=\frac{\text { Useful energy output }}{\text { Energy input }}=\frac{P_{10 a d}}{P_{\text {total }}}
\end{gathered}
$$

\section{CONCLUSION}

The province of Diyala needs electricity (1120 MW) daily while currently processing ( $520 \mathrm{MW}$ ) from only four sources. The current research is characterized by low cost design and if it is matched with other engineering designs, this cangive the advantage of spreading over the houses in the study area. For example, this proposed design has not been prepared for 2000 homes. Table 5 was calculated the outcome of the system generated by the system. Despite the simple energy it generates, the total generated by this model will be ( $166 \mathrm{Wh})$. If it takes the hours of operation $6 \mathrm{~h}$ a day, it will generate a single home (995.24 Wh). The total will be around (1990483 $\mathrm{Wh}=1.9 \mathrm{MW}$ ). A value that is not negligible because it comes from a free and renewable source. This is what aspired to in this research. This is a preliminary study that can be improved with further modifications to the initial design. Thus, it is possible to reduce the consumption of fossil fuels of all kinds and reduce the emissions resulting from the generation of electricity.

\section{ACKNOWLEDGEMENTS}

The researchers would like to express his gratitude to University of Diyala, Iraq for their financial support of this research. The researchers would also like to thank the technicians at University of Diyala for their support during the research study.

\section{REFERENCES}

Ai, B., H. Yang, H. Shen and X. Liao, 2003. Computeraided design of $\mathrm{PV} /$ wind hybrid system. Renewable Energy, 28: 1491-1512.

Bhattacharya, M., S.R. Paramati, I. Ozturk and S. Bhattacharya, 2016. The effect of renewable energy consumption on economic growth: Evidence from top 38 countries. Appl. Energy, 162: 733-741.

Cengel, Y.A. and M.A. Boles, 2002. Thermodynamics: An Engineering Approach. 4th Edn., McGraw-Hill, New York, USA., ISBN:9780072383324, Pages: 930.

Deepchand, K., 2005. Parliamentarian forum on energy legislation and sustainable development. United Nations Department of Economic and Social Affairs, New York, USA. https://sustainabledevelopment. un. org $/$ index.php?page $=$ view \& type $=13 \& n r=283 \& \mathrm{~m}$ enu $=1634$

Diaf, S., D. Diaf, M. Belhamel, M. Haddadi and A. Louche, 2007. A methodology for optimal sizing of autonomous hybrid PV/wind system. Energy Policy, 35: 5708-5718.

Diaf, S., M. Belhamel, M. Haddadi and A. Louche, 2008. Technical and economic assessment of hybrid photovoltaic/wind system with battery storage in Corsica Island. Energy Policy, 36: 743-754.

Guo, F. and R. Sharma, 2016. Hybrid energy storage systems integrating battery and ultracapacito for the PJM frequency regulation market. Proceedings of the International Conference on Power and Energy Society General Meeting (PESGM), July 17-21, 2016, IEEE, Boston, Massachusetts, ISBN:978-1 5090-4168-8, pp: 1-4.

Kaltschmitt, M., W. Streicher and A. Wiese, 2006. Erneuerbare Energien: Systemtechnik, Wirtschaftlichkeit, Umweltaspekte. Springer, Berlin Germany, ISBN: 978-3-540-28205-1, Pages: 702.

Li, J., W. Wei and J. Xiang, 2012. A simple sizing algorithm for stand-alone PV/wind/battery hybrid microgrids. Energies, 5: 5307-5323. 
Lund, H. and B.V. Mathiesen, 2009. Energy system analysis of $100 \%$ renewable energy systems-the case of Denmark in years 2030 and 2050. Energy, 34: 524-531.

Manyonge, A.W., R.M. Ochieng, F.N. Onyango and J.M. Shichikha, 2012. Mathematical modelling of wind turbine in a wind energy conversion system: Power coefficient analysis. Appl. Math. Sci., 6: 4527-4536.
McCrone, A., E. Usher, V. Sonntag-O'Brien, U. Moslener and C. Gruning, 2012. Global trends in renewable energy investment 2012. MSc Thesis, Frankfurt School of Finance \& Management, Frankfurt, Germany.

McEvoy, A., T. Markvart, L. Castaner, T. Markvart and L. Castaner, 2003. Practical Handbook of Photovoltaics: Fundamentals and Applications. Elsevier, New York, USA., ISBN:9781856173902, Pages: 986. 